\title{
Latin Books in Late Antique Egypt: Some Tentative Remarks
}

\author{
Lucio Del Corso
}

"If medical treatises are written in a language other than Greek they have no prestige even among unlearned men ignorant of Greek." This statement by Pliny the Elder seems to ascertain the presence of a barrier between Latin and medicine. It is not surprising, therefore, that the extant medical papyri are written mostly in Greek. ${ }^{2}$ Latin and Latin books represented anyway a key element in the literary landscape of Roman and Late Antique Egypt: but from their early examples to the beginning of Arab domination their cultural function and role were subjected to radical changes, even more drastic than what happened to Greek literary materials. The study of such evolutions is crucial to understand the background of the production of texts and books in Egypt, and the reception of Greek literary heritage, including the 'scientific' approach to medicine, as it is stressed in many recent studies and projects. ${ }^{3}$ This paper aims to offer a further, small contribution in this direction, focusing on the last centuries of Latin presence in Egypt, when extant materials are especially 'literary oriented', as we will see. Late antique developments, indeed, can become clearer only if compared with the previous situation: because of this, our survey will start from an interesting case study, the Fayum town of Karanis.

Karanis, in the Northern part of the nomos Arsinoites, was a small but rather rich town. Its wealth came mostly from land and agricolture: under the Antonines its granaries kept large quantities of wheat and crops, periodically sent to Alexandria,

\footnotetext{
${ }^{1}$ Plin. N.H. XXIX 17, transl. by W. H. S. Jones.

${ }^{2}$ For a complete survey on the evidence about ancient medical practices offered by Latin papyri see Marganne, Crossroads (quoting Pliny XXIX 17 at pp. 102-3).

${ }^{3}$ The role of Latin language in Egypt is superbly discussed in Adams, Bilingualism, 527-641. A global survey of Latin papyri is in progress by the team of the PLATINUM project, lead by Maria Chiara Scappaticcio (<platinum-erc.it $>$ ). Meanwhile, general surveys on Latin papyri can be found in Cavenaile, Corpus papyrorum (even if no more updated); Buzi, Manoscritti; Thomas, Latin Texts (even if limited to Oxyrhynchus); Ammirati, Libro; Seider, Paläographie, and Cavallo, Scrittura, 143-90 (both the last two about early Latin scripts). An updated, in progress bibliography can be found on the website of the CEDOPAL at Liège (URL: <http://promethee. philo.ulg.ac.be/cedopal/Bibliographies/PapyriLatinae.htm>).
} 
and from Alexandria to Rome, to be given to the plebs of the city during the frumentationes; and due to the fertility of the land and the nice weather, Karanis was chosen by many ex-soldiers and high-ranking officials, from Alexandria or elsewhere, as the perfect place to rest and invest their money when retired.

At that time, as in many other towns and villages in the Arsinoites, people from Karanis used mostly Greek for their business, and spoke a mixture of Greek and Egyptian, as in many other villages and towns: ${ }^{4}$ but some of them were also used to deal with Latin, and Latin speakers. At the end of the reign of Hadrian, one of the richest men in Karanis was Sokrates, a tax collector earning more than 10,000 drachmas each year, and living in a big house, where archaeologists from Michigan university found, in the 1930s, some of his papers. Sokrates loved Greek literature and was the owner of a small library, comprising rolls of Menander, Homer and of the Acta Alexandrinorum, and loved to add poetic quotations - from a poeta doctus as Callimachus - even when copying long tax-rolls; but for his work he needed also the knowledge of some Latin: among the texts of his dossier there are at least two Latin documents, a letter sent by a soldier doing his service outside Egypt (P.Mich. inv. 4711b, unpublished) and a contract dealing with a dowry (P.Mich. VII $442=$ ChLA V 295), in a professional cursive hand. ${ }^{5}$

Sokrates was a businessman, but in Karanis there were other individuals, less wealthy and less cultivated, not unaware of the language and the scripts of the Roman masters. One of these was Claudius Terentianus, a former sailor and then legionary, who lived in the same period of Sokrates. We know about him from another dossier of papyrus documents, found in a house of a different neighborhood of the town, inside a jar. We are not informed about Terentianus' education or literary culture, but we do see that he was skilled both in Latin and in Greek. As far as today, only 18 documents of his dossier have been published, all personal letters, almost complete. ${ }^{6}$ Seven of them are in Latin, eleven in Greek. Most of these documents are written by professional scribes, ${ }^{7}$ but Terentianus always adds a greeting formula at the end, in Latin (P. Mich. VIII 472) ${ }^{8}$ or in Greek (P.Mich. VIII 479), ${ }^{9}$ by his own hand; moreover, two texts are drafts, probably written by himself and then given to a professional scribe to be properly copied: one is in Latin, P. Mich. VIII 469, ${ }^{10}$ two in Greek (P.Mich. VIII 476 and 477). ${ }^{11}$

${ }^{4}$ This linguistic mixture has been recently studied starting from several documents, as the Narmouthis ostraka: see e.g. Menchetti/Pintaudi, Ostraka, and Bagnall, Reflections.

${ }^{5}$ Van Minnen, Karanis; Strassi, Carte.

${ }^{6}$ For a full account see Strassi, Tiberianus; see also Adams, Bilingualism, 593-7.

${ }^{7}$ See e.g. P.Mich. VIII 470-471 = ChLA XLII 1221 and 1220 (Strassi, Tiberianus nrr. 5 and 6), written by the same, skilled hand. On P.Mich. VIII 471 see also Kramer, Vulgärlateinische, nr. 3, pp. 59-74 (with full bibliography, valid for all the Latin documents of the dossier).

${ }^{8}$ ChLA XLII 1219 = Strassi, Tiberianus, nr. 7.

${ }^{9}$ Strassi, Tiberianus, nr. 14.

${ }^{10}$ ChLA XLII $1216=$ Strassi, Tiberianus, nr. 4

${ }^{11}$ Strassi, Tiberianus, nrr. 11 and 12. 
Was Karanis an exception in Roman Egypt? Probably not, even if elsewhere the traces of Latin are less evident. Exploring the Roman houses of Tebtunis, B. P. Grenfell and A. S. Hunt found several thin Latin fragments, sometimes mixed with Greek texts. One is P.Tebt. II 686, a curious papyrus, written on both sides by different, overlapping hands. On the recto, a graceful hand copies six times the incipit of Vergil's Georgics: a typical writing exercise, palaeographically ascribed to the end of the II / beginning of the III century AD; in opposite direction another, roughly contemporary hand wrote an account of payments for stone masons, painters, plumbers, and other workmen along the Nile; and on the reverse side a third hand, maybe some decades later, copied another literary text, a prose account of Herakles' labours. ${ }^{12}$

Latin papyri (and ostraka) from Egypt are very few, compared to Greek ones: some hundreds against tens of thousands. But looking at them we have anyway the impression that Latin had a plurality of funcions and usages in Roman Egypt. Latin script was employed for daily business, as we have seen, and for Roman citizens it was the language of the Law; in Egypt there were Latin books - not only Vergil, the starting-point for every student, but also less famous poets as Gallus, and historians as Sallust and Livy. ${ }^{13}$ Latin was one of the languages of the army, employed for official documents as well as for the ordinary management of the troups (as attested, e.g., by the ostraka from the garrison in Mons Claudianus). ${ }^{14}$ There were even billboards with Latin acclamations, such as P.Oxy. XLI 2950, written by soldiers of Legio V Macedonica, ${ }^{15}$ and sometimes it was chosen for public inscriptions, or funerary epigraphs. The few texts we have are scattered around all Egypt, from the chora to Alexandria.

This picture drastically changes after the III century. As it is well known, after Diocletian's reforms Egypt was divided in (two, and then more) provinces, organized according to the systems usual for all the other Roman territories. ${ }^{16}$ Scholars agree that the new administration was much more 'latinized' than the

${ }^{12}$ ChLA V 305; ChLA XI 1646; Scappaticcio, Papyri, nr. 35, pp. 175-6 (with full bibliography and palaeographical description).

${ }^{13}$ Gallus: P.QasrIbrim inv. 78-3-11/1 (LI/2); ChLA Add. 1817 (TM 59474), see Capasso/Radiciotti, Gallo. The papyri of Sallust and Livy are collected and analitically discussed in CPSGL B, 1.1 and 1.2; see also Pellé, Livre, 63-70.

${ }^{14}$ E.g. O.Claud. II 304 and 367 (or O.Did. 47, from another praesidium). See Rochette, Latin, 147-50, Fournet, Langues, 430-46, and Adams, Bilingualism, 599-623. Relevant Latin and Greek documents on Roman army in Egypt are collected in Daris, Documenti; Fink, Record (still useful, even if not up to date), and - for a specific kind of documents - Mitthof, Annona.

${ }^{15}$ Del Corso, Cultura, 206 (however Turner, the first publisher, does not exclude the possibility it was the antigraphon of an inscription).

${ }^{16}$ Bagnall, Egypt, 62-7; Bowman, Egypt, 78-88; Keenan, Egypt. The evolutions of the formal structure of provincial government went together with a "great complex of subtle changes," involving "the identity and nature of the sources of authority and the ways in which they interacted and conflicted" (Bowman, Egypt, 78). 
previous one, and sometimes infer from this assumption that the status of Latin language and script in Egyptian society changed: following a successful formula by Dagron, Latin is considered the 'language of power', opposed to Greek, the 'language of culture' ${ }^{17}$ But such contraposition does not seem to fit the extant papyrological evidence, from which a more nuanced and complex picture can be drawn. A look at the numbers, through the Trismegistos catalogue, is quite eloquent. From the establishment of Roman power in Egypt to the third century, we find in the database 343 papyri (ostraka are not included): 44 are literary or paraliterary (as lists of words or magical spells), the others are documents, either public or private, bilingual in a few cases. For the period from AD 300 to $\mathrm{AD}$ $600 \mathrm{ca}$. we find indeed 296 papyri: 140 are literary, mostly (fragmentary) codices, the others are labelled as documents, but only few are 'real' documents in Latin, and of these the far majority is no later than mid IV century; the others are documents in Greek, with a few Latin words added, as filing notes or juridical 'technical' terms. In short, papyrological evidence is much more 'literary oriented' than before. ${ }^{18}$

This shift of contents is parallel to a 'geographical' shift. If we look at the findspots of Latin papyri - when this information can be taken as granted -, for the first three centuries of the Empire we find that they are homogeneously scattered along all the Egyptian territories, as we have seen. From the IV century on, most of our evidence comes from district capitals, except for very few cases.

Such elements of discontinuity in our evidence strongly points to a drastic change of functions for Latin language and script, but along a more complex pattern than the mere opposition 'language of power' / 'language of culture'. A quick survey of extant texts - and extant books - will help us to understand this problem.

At first, the documents. Status documents (such as birth or death certificates) in Latin completely disappear in late antique Egypt: the Constitutio Antoniniana granted Roman citizenship to all the inhabitants of the Empire, and therefore such documents were no more necessary. In a few decades this implied a substantial disappearing of the bureaucratic necessities for Latin and at the same time restricted the social environments where Latin was previously used. ${ }^{19}$ The process of administrative 'Romanization' by Diocletian did not actually need an effective employ of the language of 'original' Romans. And since after Diocletian's reform the troops stationed in Egypt were mostly locally recruited, military orders were not anymore issued in a language different from locally spoken Greek.

Even high ranking officials (and officers) needed Latin only for few occasions,

${ }^{17}$ Dagron, Origines; see also Cribiore, Literacy, and Adams, Bilingualism, 545-76 (with substantial changes and original integrations to Dagron's original formulation).

${ }^{18}$ This is well explained in Fournet, Environment, 425-9.

${ }^{19}$ Fournet, Environment, 423. 
as we may see from the archive of Flavius Abinnaeus, praefectus alae Quintae Praelectorum, stationed in the fortress of Dionysias around the middle of the IV century AD. This 90-documents dossier comprises 14 petitions, addressed to Abinnaeus by lower-ranking officials or soldiers, all in Greek; only two texts are in Latin: one is a petition addressed to the Emperors by Abinnaeus himself, the other is an official letter written by the dux Aegypti Valacius to remove Abinnaeus from his command. ${ }^{20} \mathrm{~J}$. N. Adams, commenting such texts, pointed out that Latin is used here as a "'super-high' language which could be employed either to make obvious the location of supreme power, or in appeal to a supreme authority." ${ }^{21}$ But if this is true, Latin played such a role in late antique Egypt only in a very few occasions and for a short period.

The choice of Latin for the removal order of Valacius is rather unique: and even if we have other official documents in that language issued by high authorities, their chanceries usually employed Greek, especially for peremptory orders. A good example is P.Oxy. L 3577 (TM 15398), written in the office of the praeses Augustamnicae Flavius Iulius Ausonius in AD 342, two years before Valacius' order. The letter imposes two important citizens of Oxyrhynchus to pay a large sum of money, a potentially catastrophic event: its authoritative nature is graphically expressed by the Greek script employed, a complex and rather baroque chancery script, which was used exclusively by central offices ${ }^{22}$ and therefore was perceived as the standard expression of power by all Egyptian citizens. There is only one Latin element in this order: the filing record, mentioning the ruling Emperors. In late antique documentary production the space of Latin is commonly limited to such small notes, which can be found especially in legal proceedings ${ }^{23}$ or documents from high offices: it seems nothing more than a bureaucratic frame, lasting for one century or more, but as a pure convention.

When we turn to the realm of book and book production, we move to a rather different landscape. As we have seen, even if many interesting Latin book fragments found in Egypt arrived in museums and libraries throught the gloomy tunnels of black market, our evidence mostly comes from larger urban centres, and especially from Hermoupolis, Oxyrhynchus and Antinoupolis. Unfortunately, archaeology does not help us to give a social profile to the owners of such books: differently from what we have seen in Karanis or Tebtunis, we have not yet found Latin books in contexts related to urban structures, as houses, but only in rubbish mounds, where completely different materials are mixed together, so

\footnotetext{
${ }^{20}$ The documents are gathered together and commented in P.Abinn.

${ }^{21}$ Adams, Bilingualism, 557.

${ }^{22}$ Cavallo, Calamo, 17-42.

${ }^{23}$ A list of such documents is provided by Coles, Reports (for a quick reference see also Palme, Texts); their palaeographic relevance is well discussed in Cavallo, Calamo, 48-53.
} 
that it is difficult to discern their original provenance. Moreover, Grenfell and Hunt did not like too much giving plain information about the places of their excavations, mostly to preserve them from clandestine diggers. ${ }^{24}$

Indeed, some significant details are provided by J. de Monins Johnson, the first 'scientific' digger of Antinoupolis' mounds, where almost all of the city's extant Latin papyri come from. Antinoupolis is a very good case study: it was the residence of the comes et dux Thebaidos, and if Latin was really the powerful tool of an élite of technocrats, we would expect to find some signs of this linguistic supremacy especially there. But archaeology shows a different picture.

Johnson was not a seeker as lucky as Grenfell and Hunt (and surely he was less brilliant as a papyrologist, though his contribution to classics and humanities is nevertheless huge: it is mostly thanks to his efforts as Printer for the University of Oxford if the Oxford Press never stopped to work even during the Second World War), ${ }^{25}$ but his report about the excavations in Antinoupolis is the only scientific description of the methods employed by British archaeologists when working on rubbish mounds. ${ }^{26}$ From this report we can infer that our papyri were not homogeneously scattered around all the rubbish area, but were concentrated especially in selected spots; most of the Latin fragments come from a corner close to the northern wall of the city, marked with the letter $M$ in the plan published by Johnson. ${ }^{27}$ Today this area has the general appearance it had on the beginning of the XX century, but the mounds are mostly composed by pottery and sand, without the precious $a f s h$, the special soil which can preserve fragile papyrus and other organic remains for centuries. ${ }^{28}$ Here Johnson found a concentration of parchment and papyrus codex leaves, clearly discarted together at the same time: to use his words, "the tattered fragments of what must once have been a small Byzantine library." This hypotethical library - we cannot know whether public, or private, or ecclesiastic... - kept together Latin and Greek books: Greek authors as Euripides, Theocritus and Dioscorides stayed together with Vergil, Ulpian and with a strange bilingual manual, teaching greek tachygraphy and some Latin calligraphy. ${ }^{29}$ This coexistence of fragments in both languages could be physically perceived by the excavators: in that sector, at a small distance from the "patch of ashes in the interstices of the sherds" which gave back substantial fragments of a Theocritus codex,${ }^{30}$ a "ball of papyrus" was

${ }^{24}$ On Grenfell and Hunt's excavations in Oxyrhynchus see at least Coles, Oxyrhynchus, and Turner, Branch.

${ }^{25}$ See Andorlini, Scavi; O'Connell, Johnson; Malouta, Archive.

${ }^{26}$ Johnson, Antinoë. See also O'Connell, Johnson, 417-20.

${ }^{27}$ Johnson, Antinoë, 173, reproduced also in O'Connell, Johnson, fig. 1.

${ }^{28}$ See the classic account in P.Fay., pp. 24-5; Davoli, Archeologia, 5-7.

${ }^{29}$ A preliminary survey of literary papyri from Antinoupolis can be read in Menci, Papiri, with substantial addings in Fournet, Antinoupolis (focused anyway only on the papyri found in the Italian excavations from the late ' 30 s to the present).

${ }^{30}$ Hunt/Johnson, Theocritus, 19-87 + P.Ant. III 207 (TM 62814). 
found, used as a jar-stopper, and comprising a Greek document (the "fragments of a land register") and a Latin poetical text. In the following editions of papyri from Johnson's excavations there are no other references to this: but we may suppose that this Latin text was the Vergil P.Ant. I 29, or even the famous Juvenal fragment, whose conditions seem to be compatible with that humble reuse (but the manuscript is properly on parchment). ${ }^{31}$

Therefore, we apparently have the traces of an élite of cultivated individuals practising both Greek and Latin literature, but using for their business only Greek. If we turn our attention to the material characteristics of such Latin books and to their content, we can understand something more about the cultural coordinates determining the choice of Latin.

Late antique Latin books from Egypt are usually well done. The writing materials employed - both papyrus and the more expensive parchment - are of good quality; their size is huge for the standards of that period: they are often around $30 \mathrm{~cm}$ tall and $20-25 \mathrm{~cm}$ broad, with large, blank margins, as the Aeneis PSI I 21 (ChLA III 287; TM 62966), ${ }^{32}$ from Oxyrhynchus; but we find also over-size books, as another Vergilian book, the already mentioned P.Ant. I 29 (ChLA Suppl. 1708; TM 62956), $41 \mathrm{~cm}$ tall and $27 \mathrm{~cm}$ broad, with only 25 verses for each page and an extant, lower margin of more than $9 \mathrm{~cm} .{ }^{33}$ Few codices have a two-columns layout, as the impressive Ulpian P.Ant. I 22 (ChLA Suppl. 1707; TM 62940): this rather uncommon feature - except for bilingual manuscripts - is distinctive of deluxe editions. As it is normal for early codices, decorations and colophons are lacking, but these books were written by professional hands, or anyway by hands which were given a specific calligraphic training. A few fragments are in elegant, 'rustic' capitals (if I may use an 'out of fashion' and improper palaeographical label): ${ }^{34}$ this is the case of two beautiful albeit fragmentary - manuscripts form Antinoupolis, PSI XIII 1306 (Paul's Epistles; ChLA Suppl. 1694; TM 61867) and another Aeneis, P.Ant. I 30 (ChLA Suppl. 1709; TM 62961), ${ }^{35}$ the former assigned to the IV, and the latter to the V AD. The most characteristic script is, anyway, the uncial, in its different typologies (as especially the 'B-R type') ${ }^{36}$ : uncial manuscripts found in Egypt can compete with the best examples from the West, as it is clear if we only

${ }^{31}$ The 'Antinoë Juvenal' was published for the first time in Roberts, Juvenal; on the papyrus see also infra, footnotes 51 and 52. With "fragments of land register" the report could refer e.g. to a text such as P.Ant. III 205 (reproduced in O'Connor, Johnson, fig. 96), but we cannot be sure.

${ }^{32}$ Scappaticcio, Papyri, nr. 17.

${ }^{33}$ Scappaticcio, Papyri, nr. 34.

${ }^{34}$ On the limit of this definition see Pratesi, Divagazioni, 6-8 (= Id., Frustula, 192-4); Del Corso, Cultura, 208 (with further bibliography).

${ }^{35}$ On PSI XIII 1306 see Minutoli, Considerazioni; on P.Ant. I 30 Scappaticcio, Papyri, nr. 27 (dating the papyrus to the $\mathrm{V} \mathrm{AD)}$.

${ }^{36}$ See Cavallo, Scrittura, 184-90; Cavallo/Fioretti, Chiaroscuro, 48-63. 
consider the Antinoupolis parchment of Gaius, PSI XI 1182 (ChLA II 292; TM 59956), written in the V/VI AD by a calligrapher who embellishes his work with enlarged initials and rubrications. ${ }^{37}$ Half-uncial, too, is quite common ${ }^{38}$ It can be found sometimes in uncial manuscripts, for collateral texts: the above mentioned 'king' Vergil P.Ant. I 29 was written in uncial, but before the beginning of each book it had a prose argumentum - a synopsis of what was going to happen in that section - written in half-uncial by the same, very careful and elegant hand. Half-uncial was employed also for whole books, usually of juridical content (as legal commentaries), even if it is attested also in the transcription of 'classical' authors, as in PSI I 110 (ChLA III 288; TM 62689), from Oxyrhynchus, a IVcentury copy of Sallust's De coniuratione Catilinae: the hands using this script can be quicker - as it is PSI I 110 - or slower - as, among the many examples, the juridical fragment P.Ant. III 153 (ChLA Suppl. 1789; TM 65085) - but they all show a professional proficiency.

Literary texts in more generic minuscules or informal scripts are only a few: we find a curious example in P.Oxy. LII 3660 (ChLA Add. 1834; TM 64594), a list of alphabetically ordered Latin words, mostly with some literary taste (such as the toponym Lilybaeum, used by Livy and other Roman historians); it was written in the IV/V century in a quick minuscule by two hands working together, we do not know if for teaching or other educational purposes.

Thus, the far majority of Latin books found in Egypt are professionally made and written books. This is a noteworthy point, especially if you compare it with Greek book production: Greek books written in rapid, nondescript hands, sometimes 'home-made' - we can suppose - by their readers, are very frequent, and they often outnumber 'professional', luxury books written in normative scripts. ${ }^{39}$

Such level of book-craft rises a question: where were our extant Latin books from Egypt written? Were they an Egyptian product or do we have to think that they were copied in other countries? This is a crucial point, influencing the whole picture of the diffusion of Latin in late antique Egypt.

Unfortunately, we do not have any scribal colophon giving us informations about the time or place of the work of copy: and such colophons, by the way, are substantially lacking in books from the East, at least until the Byzantine Middle Age. We can rely only on palaeography, a slippery ground, but full of useful suggestions. Latin palaeographer E. A. Lowe, examining the characteristics of a

${ }^{37}$ For this characteristic script see the concise remarks by Cavallo, Scrittura, 184-90; on the diffusion of the 'B-R uncial' in the East of the Empire (and especially in relation with juridical texts) crucial remarks in Nicolaj, Ambiti, 479-83, and in Cavallo/Fioretti, Chiaroscuro, 54-6.

${ }^{38}$ Even if problematic from a paleographic point of view, I still adopt the definition of 'half-uncial', commonly employed by Elias Lowe in the volumes of ChLA: see at least Cavallo, Scrittura, 184-5.

${ }^{39} \mathrm{We}$ do not yet have full statistics for this, especially for late antiquity, but see e.g. Johnson, Book, 263 ("If a third of bookrolls were written with some elegance, more than half were written in fairly rapid, nondescript hands"). 
St. Augustine uncial manuscript in Lyon (cod. 478), suggested that the bookhand that transcribed that codex was affected by 'Greek symptoms', and that the same symptoms, 'affecting' both letter forms and layout, could be found in a larger number of Latin late antique manuscripts, on parchment and papyrus, mostly coming from Egypt. ${ }^{40}$ Because of this, he supposed that the uncial used for these manuscripts - the 'B-R uncial' - was typical of the East part of the Empire, and stilistically different from 'Western' uncials, characteristic of manuscripts written, e.g., in Italy.

As a consequence of the high scribal level of such manuscripts, Lowe suggested that the most suitable place for their manufacture was the capital of the Eastern empire, Constantinople, where a production of Latin books is well attested by literary evidence. ${ }^{41}$ But Lowe did not categorically deny other possibilities, as Berytus or Alexandria, even if in his opinion such cities could not guest artisans able to produce such 'masterpieces of calligraphy' as those manuscripts. During the last decades, some scholars - mostly papyrologists and palaeographers - have turned Lowe's nuanced prudence into a taxative prescription. So, Latin late antique books found in Egypt have been systematically ascribed to other Eastern provinces: the folios in beautiful uncial scripts, as PSI XI 1182, to Constantinople; others, in half-uncial (such as e.g. P.Ant. III 153) or less elegant uncials, to other cities, as Berytos, where Latin schools are attested at least by Libanios. But such a drastic expulsion of Latin book production from Egypt is too a simplistic solution. ${ }^{42}$ At first, it seems to underestimate the richness and complexity of Alexandrian cultural life during late Antiquity; ${ }^{43}$ sciences - especially mathematics and astronomy -, philosophy and medicine were relatively popular subjects, and debated in city schools; in Alexandria there was a chair of Law until the reign of Justinian, and that teaching, even if less formal than the one given in Constantinople, implied the knowledge of some Latin; ${ }^{44}$ last but not least, in Alexandria there were poets able to write in Latin as well as in Greek: the most famous of them is Claudius Claudianus, born in Alexandria, who moved to Rome only when he was almost thirty. And if in Alexandria there were poets who knew Latin, it is likely that Latin books could be written there.

But there is also something less impressionistic. Many manuscripts written in semi-uncial have a juridical content, as we have mentioned and as we will see better in a while: they are mostly commentaries or more generic 'tools' for the correct application of Roman law. We know from several sources that in Egypt

\footnotetext{
${ }^{40}$ Lowe, Symptoms.

${ }^{41}$ Bianconi, Graeca.

${ }^{42}$ Ammirati, Osservazioni, 81 n. 81.

${ }^{43}$ On late antique Alexandria's intellectual life see Haas, Alexandria, esp. 121-7 (culture of the Jewish community), 150-72 (pagan community), 181-90 (Christian community), and passim; but see also Ruffini, Networks.

${ }^{44}$ Corcoran, Tales, 193-4.
} 
as far as the VI century there were skilled nomikoi, lawyers and scholastici so proficient in Roman law to write their own summaries and interpretationes: the most famous is Theodore the Theban, who wrote an extensive commentary to Justinian's Codex and later a bilingual Breviarium novellarum, published some years before the 602 and still extant in a couple of Byzantine manuscripts. ${ }^{45}$ Theodore lived and worked mostly in Hermoupolis, not far from Antinoupolis. Several Latin fragments of juridical content come from Hermoupolis, for a period from IV to VI century $\mathrm{AD}$, the most famous being the so called Fragmentum de formula Fabiana, BKT IX 200 (ChLA VIII + X 1042), written in a characteristic, slightly sloping half-uncial assigned to the IV/V century $\mathrm{AD}^{46}$. We cannot leave unrelated such evidence: if literary sources tell us that during late antiquity there were scholastici born in Hermoupolis who were able to write legal commentaries, there are no reasons to suppose that papyri found in that city and bearing that kind of texts were written elsewhere. ${ }^{47}$ And the halfuncial attested by the Fragmentum de formula Fabiana is used also for other manuscripts of different contents: as we have seen, the same script is employed e.g. in the Vergil P.Ant. I 29, by a bookhand who can also write a beautiful uncial. If this is true, there are no cogent reasons to look for the place of writing of such manuscripts elsewhere than Egypt. Probably, there were graphic models common to all the Eastern part of the Empire, ${ }^{48}$ as there were for Greek scripts, ${ }^{49}$ and this implied that scribes learning the art of calligraphy were given very similar teachings, in the main cities of Egypt as well as in the Nea Romi Constantinople, even if we can believe that in the Capital the qualitative standars for book production were better than in other cities. And probably, since the mobility of ancient books was higher than what we usually think, in Egypt there were Latin books really written in Constantinople or Berytus, as well as Greek books written in Italy or in Greece: ${ }^{50}$ but the bulk of Latin manuscripts found in

\footnotetext{
${ }^{45}$ RE V.A.2, coll. 1863-5 (Theodoros 43); PLRE 3, Theodorus 64; Corcoran, Tales, 193.

${ }^{46}$ Palaeographical and codicological analysis in Ammirati, Osservazioni, 67-8; she assigns the manuscript to the IV century, as already proposed by Lowe, ChLA VIII + X 1042; Cavallo, Scrittura, 184 (pl. 153) prefers the IV/V.

${ }^{47}$ The origin of the Fragmentum is sometimes said to be 'Syria' in palaeographic literature (a possibility not excluded by Ammirati, Osservazioni: "una provincia orientale"), desuming this from Lowe's remarks. It may be interesting to follow the process behind this suggestion. In the first reference to it in ChLA VIII 1042 (p. 6) Lowe (correctly) states: "Origin uncertain. Found at Eschmunen-Hermoupolis"; later, describing the Vienna sheet of the manuscript he adds: "written presumably in a centre of legal studies in the Eastern part of the Empire" (ChLA X 1042, p. 27). Syria is explicitly mentioned as "the home of the Fragmentum" only in ChLA Suppl. 1710, p. 13, in the discussion of the provenance of another fragment, the Antinoupolis Juvenal: and, in a sort of short circuit, the latter is said to be from that region because of its similarities with the Fragmentum...

${ }^{48}$ Nicolaj, Ambiti, 480-1.

${ }^{49}$ Cavallo, Calamo, 9, 39-42 (documentary scripts); Crisci, Scrivere, 179-82.

${ }^{50}$ Cavallo, P.Mil. Vogl. I 19.
} 
Egypt was originally written there, even if it is not possible to specify whether in Alexandria or in other cities.

What are the social implications of this? What was the ultimate purpose of such a skilled book craft, while Latin language was less and less useful for documentary practices, for ordinary business, for daily life? A quick survey of the contents of the extant papyri and parchments can help us to understand the reasons of this long surviving.

Two preliminary, general remarks are noteworthy. At first, in spite of their palaeographical value, our manuscripts are quite monotonous and homogeneous: in Antinoupolis the same authors and the same kind of texts were read as in Hermoupolis or Oxyrhyncus. Moreover, our manuscripts are usually pointed by many orthographic mistakes, mostly of phonetic origin, even when they preserve variants of some value: they were evidently copied by scribes more used to Greek than Latin language. With such premise, let us turn to examine the contents of those books.

Only very few of our texts can be referred to school or scholastic practices, and neither of them is a school exercise of basilar, elementary level, a kind of evidence now much better understood, thanks to the works by Raffaella Cribiore. ${ }^{51}$ We have indeed some handbooks written for scribes or other professional writers who already had a proficiency in Greek script and needed to improve their knowledge of Latin. The best example is the so called "shorthand manual" from Antinoupolis, kept in Oxford, Sackler Library (ChLA Suppl. 1705; TM 64342). ${ }^{52}$ "Shorthand Manual" is a reductive label for this book: it was a companion aimed to help to read and write different kinds of tachigraphic systems and abbreviations. We can reconstruct only a part of two quires of this V-century papyrus codex, and so we do not know how long the original text was: in this treatise, anyway, the discussion of Greek abbreviative systems was followed by a Latin section, of which only the very beginning survives. The 'first lesson' of this section was the Latin alphabet, but not the standard 'majuscule' letters: rather, half-uncial letters, surmounted by their phonetic pronounciation in Greek characters; these lines are followed by another alphabetic sequence, in a different script: an elaborated and heavily decorated capital. This was not a tool for a schoolboy, but for professionals, or other cultivated individuals, who needed to quickly learn special writing systems, ${ }^{53}$

\footnotetext{
${ }^{51}$ See e.g. Cribiore, Writing, 139-52.

${ }^{52}$ The main fragments are published in Milne, Shorthand, as Pap. Antinoë 1 (with plates); it has been suggested that P.Sijp. 5, kept in Florence, "Istituto Papirologico G. Vitelli" (PSI inv. 1935), could be part of the same manuscript, but this is very uncertain: see Del Corso, Osservazioni, 17982. Another 'shorthand manual' of large dimentions, and written by a calligraphic hand, is P.Vat. Gr. 57, published in Harrauer/Pintaudi, Miscellanea, 118-33.

${ }^{53}$ Rochette, Latin, 178-9; Scappaticcio, Abecedari, 487-90; Ead., Artes, 77-87.
} 
and similar conclusions can be drawn about extant Greek-Latin glossaries to authors as Vergil and Cicero, which in late antiquity are conceived as bilingual editions of their most important works. ${ }^{54}$

Only a couple of fragments, even if of great importance, are copies of sacred texts: the most interesting is perhaps the parchment strip from Antinoupolis, PSI XIII 1306. As we have cursory seen, in this meagre remain of a 'deluxe' edition of Paul's Letters the left-hand column, with the Greek text, was in Biblical majuscule, the right-hand one in elegant Latin capitals. We do not know if such a beautiful manuscript could have a liturgic purpose. We can say, however, that our literary evidence points out the existence of monastic milieux where different languages were practiced: we know, for example, of monks who could read sacred books written in Greek, Coptic, and Latin. ${ }^{55}$ And the comparison of different versions - for scripts and languages - of the sacred texts has a long tradition in Christian scholarship: ${ }^{56}$ behind a lonely manuscript treasure as PSI XIII 1306 there are probably manifold needs.

The majority of our literary fragments falls in two other categories: works of classical authors and juridical texts. The surviving selection of classical authors comprises some Cicero, Sallust, and Livy, but the bestseller was by far Vergil, whose Eclogues, Georgics and Aeneid are found in many different copies. ${ }^{57}$ No author later than Juvenal is attested. Behind such highly canonized selection there seems to be the 'shadow' of the school, and of the selective choices of grammarians. This is true, in a sense: in the ancient world, authors long canonized by school conventions were also the most widespread among the general public, which often found them the most suitable for their own cultural needs (even if other texts and other, less aulic authors were read and appreciated as well). But this does not mean that our Egyptian papyri come from effective scholastic milieux. Indeed, marginalia and paratextual elements added on them suggest different reading contexts. The abovementioned Vergil P.Ant. I 29 is a good example: as we have seen, it was equipped with prose summaries of the content of each book, written in half-uncial, a script not suitable for beginners. Such paratextual aids seem to be meant for readers already proficient in Latin, but not erudite, nor learned enought to understand a text so far from their cultural horizons, such as the works of an Augustan poet, without some help.

${ }^{54}$ For a general survey see Radiciotti, Digrafismo (with reference to the many previous contributions on the topic by the scholar). For the extant glossaries to Vergil (ten papyri, ranging from the second half of the IV to the VI cent. AD) see especially Fressura, Tipologie and Vergilius; on Cicero (four papyri) see indeed Internullo, Cicerone, and Ammirati, Cicerone, 22.

${ }^{55}$ Hist. monach. in Aeg. 6,3 (pp. 44-5 Festugière); 8,62 (pp. 70-1 Festugière): see Rochette, Latin, 151-2. A trilingual Latin-Greek-Coptic 'handbook for conversation' is C.Gloss.Bil. I 15 (new commented edition, with full bibliography, in Dickey, Speakers).

${ }^{56}$ Grafton/Williams, Christianity.

${ }^{57}$ Surveyed in Scappaticcio, Papyri. 
The notes on the margins confirm this reconstruction: they are added by the hand of a reader, less fluent than that of the scribe who wrote the main text, and aim to give explanations of difficult words or difficult mythological references, or to indicate some nice passages. ${ }^{58}$

There were also more advanced readers, who could approach a Latin classical text in a more elegant philological perspective. Some traces of them can be seen in a rarity as the Juvenal parchment from Antinoupolis. ${ }^{59}$ The only extant leaf is literally covered by the annotations of three different hands, on the margins and in the interlinear spaces. One of them - the latest, hand $\mathrm{C}$ in Robert's reconstruction - uses only Greek, mostly to note the translation or explaination of some words or passages; the other two, probably a little earlier, put accents and quantity marks on the syllables, explain difficult passages, sometimes add their personal opinion on what the poet says (as on verses 190 and followings, when hand B remarks eruditus est solus qui pauper est nec molestias timet). But above all, hand A and hand B employ critical signs typical of Greek grammatical tradition: one of this is the diple 'reinforced' with a line (diple obelismene), traditionally used to signal textual difficulties or spurious passages, and here placed on verses 192-194, an obscure section, suspected by modern philologists and transmitted with many variants by Medieval manuscripts. ${ }^{60}$ The readers of the Antinoupolis Juvenal cannot be considered brilliant scholars, but they were aware of all the textual problems of the poems which they carefully read and studied. In Antinoupolis a similar attitude is expressed by other readers, but especially for Greek texts: the most famous case is the Theocritus codex, read and annotated by two hands which employ the same conventions and the same diacritical signs used by the hands of the Juvenal. ${ }^{61}$

However, the love for philology, or more in general for the textual legacy of classical Latin authors, was only one of the reasons justifying the transcription of Latin books in late antique Egypt. The most important was another one: the need for an accurate knowledge of the mechanisms of Roman Law.

The majority of our Latin books from Egypt are related to law or jurisprudence. ${ }^{62}$ Among such materials we find impressive manuscripts, as the

\footnotetext{
${ }^{58}$ Such annotations are re-edited and briefly discussed in McNamee, Annotations, 491-2.

${ }^{59}$ Roberts, Juvenal; ChLA Suppl. 1710; TM 61415. The parchment is conventionally assigned to " $c$. 500 AD" both by Roberts, Juvenal, 201, and Lowe in ChLA (followed by Ammirati, Osservazioni, 96); Seider, Paläographie II.1, 132, Abb. 53, suggests a slightly broader range, i.e. V/VI AD.

${ }^{60}$ On the different shapes and usages of the sign, from its 'Alexandrian' origins to later evidence in Greek papyri, in all its different shapes, see Pfeiffer, History, 175, 178, 218; Turner, Papyri, 117-8.

${ }^{61}$ Study and new edition of these marginalia in McNamee, Annotations, 479-90; see also Nocchi Macedo, Juvenal, and Scappatticio, Artes, 482-98. For the annotations on the Theocritus codex see McNamee, Annotations, 376-427.

${ }^{62}$ Relevant evidence is collected and discussed in Migliardi Zingale, Diritto and Dottrina; Ammirati, Book and Osservazioni (a full survey of all Latin juridical papyri).
} 
above mentioned, huge Ulpian P.Ant. I 22, written in beautiful uncials on two columns, or Gaius' Institutiones PSI XI 1182, a masterpiece of late antique book craft. High quality parchment codices were used also for editions of corpora legum, as P.Oxy. XV 1814 (ChLA Suppl. 1713; TM 65083), the most ancient extant copy of the Codex Iustiniani. ${ }^{63}$ Together with 'official' texts we find a large quantity of minor, secondary works: selections and paraphrases of laws, commentaries on specific dispositions, exegetic and procedural materials of different kind. This textual galaxy can be at least in part connected with the informal teachings and the activities of scholastici with intellectual ambitions, as the above mentioned Theodore from Hermoupolis: and as such, they are often not so sophisticated, nor stylistically elaborated. But such not so original compilations were accurately transcribed on specific books, expressly developed for that kind of works and characterized by a strong interaction between the main text and the annotations, through the adoption of peculiar layout and scripts. Let us consider another manuscript from Antinoupolis, P.Ant. III 152 (ChLA Suppl. 1711; TM 64897), a VI-century commentary on a disposition of law from the Corpus iuris civilis: the text of the law is paraphrased in Latin and transcribed in the middle of the page, in medium-sized uncials; on the margin, 'technical' and procedural explainations are written, by the same hand but in a 'mixed' language, where Latin terms are inserted in a Greek context. ${ }^{64}$ For this 'mixed language' a mixed script is used, where half-uncial letters join a quick sloping majuscule of ogival type, but with cursive infiltrations. The Greek basis of this script was currently used by lawyers and notarioi, as we can see in many V- or VI-century documents from the same region, as for example in the archive of Dioscorus. ${ }^{65}$ And the disposition of the marginalia was not casual nor irregular, but was planned by the scribe in order to let the reader find the informations he needed. A similar setting can be seen in other manuscripts, as P.Ant. III 153 (ChLA Suppl. 1789; TM 65085), a VI-century commentary on the law of dowry, ${ }^{66}$ or in P.Ryl. III 474 (ChLA Suppl. 1722; TM 61414), a commentary to the Digest written a century later in the Thebaid. ${ }^{67}$

The array of 'written tools' developed for juridical practices was much wider. Synoptic tables and summaries are quite frequent, as we can see in two codices from Oxyrynchus, P.Ryl. III 476 (ChLA II 225; TM 64583) ${ }^{68}$, a V-century register of imperial constitutions in Greek and Latin, and especially in the abovementioned Justinian Code P.Oxy. XV 1814, whose extant fragments

\footnotetext{
${ }^{63}$ Corcoran, Justinian.

${ }^{64}$ New edition in McNamee, Annotations, 507-8 (with plate).

${ }^{65}$ Del Corso, Dioscoro, 102-11.

${ }^{66}$ McNamee, Annotations, 508-11 (with plate); Ammirati, Osservazioni, 71.

${ }^{67}$ McNamee, Annotations, 507; Ammirati, Osservazioni, 89.

${ }^{68}$ McNamee, Annotations, 505-6; Ammirati, Osservazioni, 71.
} 
contain a catalogue - in Latin, but with Greek titles - of the Novellae included in the first edition of the Code, to be assigned to the years $529-535 .{ }^{69} \mathrm{We}$ do not know if such texts were indexes of large compilations of laws, or if they should be considered only as reference tools: a Graeco-Latin register of laws is added, for example, at the beginning of Theodore's Breviarium. But we can be pretty sure that P. Oxy. XV 1814 was not part of a complete edition of the Codex Iustiniani. On the right margin of the verso it is possible to read remains of pagination, with the number , twenty-five: this number is too high for a beginning index, and too low for the end of a book. There were probably other legal materials, before, but we cannot know what they were. $^{70}$

Such manuscripts, so different for physical features, contents, and general layout, were intended to answer to the needs of a specific cathegory of readers: the lawyers, the notarioi, the scholastici, all the professionals ${ }^{71}$ involved with the application of Roman laws and its complex procedures. These individuals were not only able to read and write in Greek, mastering also difficul cursive scripts, but for their work they needed also rhetorical knowledges, at least on a basilar level: in late antiquity petitions, requests to high authorities or even more basilar documents as wills and contracts followed complex formularies, and could not be accepted without an adequate level of rhetoic. ${ }^{72}$ And rhetoric was impossible to learn without the knowledge of classical literature. It is not casual if the best known VI-century lawyer from the Thebaid, Dioscorus, was the owner of a small library, comprising at least manuscripts of Homer, commentaries to the Homeric poems, Menander and even a not so well-known comic poet as Eupolis; Dioscorus, by the way, loved to compose occasional poetry, in his spare time (even if with not so good results). ${ }^{73}$ Moreover, we are quite sure that he had at least a basilar knowledge of Latin, since he was used to include Latin words in his documents to refer to legal ideas: in a long will written around 570 (P.Cair.Masp. II 67152, 11. 64-66), he uses several time the Latin verb confirmo (sometimes turned in a Greek form of participle: confirmateumenos), to express that the dispositions of his client were stronged by the present document. ${ }^{74}$ Dioscorus was born and lived in a small town of Thebaid, Aphrodito, but spent a large part of his working time in Antinoupolis, and sometimes even further. How many Dioscori were there in other cities of the region, such as the close Hermoupolis, and more in

\footnotetext{
${ }^{69}$ Ammirati, Osservazioni, 83-4.

${ }^{70}$ For the remains of pagination see P.Oxy. XV, p. 219.

${ }^{71}$ See the list in Harrauer, Handbuch, 82-94.

${ }^{72}$ Fournet, Document.

${ }^{73}$ On Dioscorus' life see MacCoull, Dioscorus; on his culture and his books Fournet, Hellenisme, esp. 669-90. Dioscorus' poems are republished - with impressive commentary - in Fournet, Hellenisme (as P.Aphrod.Lit. IV); for a study of their literary characteristics see Agosti, Dioscoro.

${ }^{74}$ Fournet, Environment, 427.
} 
general in Egypt? We are not able to give a final answer: but it is very probable that our Latin manuscripts belonged mostly to individuals like him, except for a few amateur philologists or other eccentric intellectuals.

Is it possible to draw any conclusions from our survey? Probably not. Our Latin papyri are crepuscular materials, as the remains of a sunny day, and not only because of their small number, but for their residual nature. The administrative normalization of Egypt imposed by Diocletian had a paradoxical consequence: it determined in few decades the exit of Latin from daily life for all the inhabitants of that part of the Empire. And this was followed by another, even more radical geopolitical shift: for centuries Egypt had had the role of a bridge between the East and the West; after Diocletian, the country of the Nile returned to the Eastern sphere, and the relationships with Italy, much more ancient than the Roman rule, were progressively cut off. The new geography of power implied a new geography of languages: and in this new background Latin, after centuries of coexistence with many other idioms, had a very limited space. Its only real niche was the realm of Law. Here Latin not only survived, but kept its own vitality; and the best proof of this vitality - even if it may seem ironic is the graphical and linguistic hybridization with the Greek, in order to create suitable tools for different kind of juridical practices. The knowledge of the ancient literature of Rome was as well mostly functional to the traininig of good lawyers and officials.

In few decades, Latin became a language of culture, and of a specific, technical culture: but neither law nor literature can justify the surviving of a language. Its long twilight, in a country which was once a real trait d'union between different worlds, is the beginning of a cultural contrast which evolved, during the centuries, in different directions, and even today seems far to be resolved.

\section{Bibliography}

Adams, Bilingualism = James N. Adams, Bilingualism and the Latin Language, Cambridge 2003.

Agosti, Dioscoro = Gianfranco Agosti, Il ruolo di Dioscoro nella storia della poesia tardoantica, in: Fournet, Dioscore, 33-54.

Ammirati, Book = Serena Ammirati, The Latin Book of Legal Content: A Significant Type in the History of the Ancient Book, in: P. Schubert (ed.), Actes du 26e Congrès international de papyrologie. Genève 16-21 août 2010, Genève 2012, 19-25.

Ammirati, Cicerone $=$ Serena Ammirati, Leggere Cicerone in Egitto: osservazioni paleografiche (e filologiche), in: P. De Paolis (ed.), Dai papiri al XX secolo. L'eternità di Cicerone. Atti del VI Simposio Ciceroniano, Arpino 9 maggio 2014, Cassino 2015, 11-29.

Ammirati, Libro = Serena Ammirati, Sul libro latino antico. Ricerche bibliologiche e papirologiche, Pisa/Roma 2015.

Ammirati, Papiri $=$ Serena Ammirati, Per una storia del libro latino antico: $i$ papiri latini di contenuto letterario dal I sec. A.C. al I ${ }^{\text {ex. }}$-II ${ }^{\text {in. }}$ D.C., "Scripta" 3 (2010), 29-45. 
Ammirati, Osservazioni $=$ Serena Ammirati, Per una storia del libro latino antico. Osservazioni paleografiche, bibliologiche e codicologiche sui manoscritti latini di argomento legale dalle origini alla tarda antichità, JJP 40 (2010), 55-110.

Andorlini, Scavi = Isabella Andorlini, Gli scavi di John de Monins Johnson ad Antinoe (19131914)", in: Del Francia Barocas, Antinoe, 19-22.

Bagnall, Egypt = Roger S. Bagnall, Egypt in Late Antiquity, Princeton 1993.

Bagnall, Handbook = Roger S. Bagnall (ed.), The Oxford Handbook of Papyrology, Oxford/New York 2009.

Bagnall, Reflections = Roger S. Bagnall, Reflections on the Greek of the Narmouthis Ostraka, in: M. Capasso / P. Davoli (eds.), New Archaeological and Papyrological Researches on the Fayyum. Proceedings of the International Meeting of Egyptology and Papyrology. Lecce, June $8^{\text {th }}-10^{\text {th }}$ 2005, Galatina 2007, 15-21.

Bianconi, Graeca = Daniele Bianconi, Alle origini dei Graeca di Prisciano. Il contesto culturale e librario, in: L. Martorelli (ed.), Greco antico nell'Occidente carolingio. Frammenti di testi attici nell'Ars di Prisciano, Hildesheim/Zurich/New York 2014, 319-39.

Bowman, Egypt = Alan K. Bowman, Egypt after the Pharaos, 332 BC-AD 642: from Alexander to the Arab Conquest, London 1990.

Bowman/Coles/Gonis/Obbink, Oxyrhynchus = Alan K. Bowman / Revel A. Coles / Nick Gonis / Dirk Obbink / Peter J. Parsons (eds.), Oxyrhynchus. A City and Its Texts, London 2007.

Buzi, Manoscritti = Paola Buzi, Manoscritti latini nell'Egitto tardo-antico, Imola 2005.

Capasso/Radiciotti, Gallo = Mario Capasso / Paolo Radiciotti, Il ritorno di Cornelio Gallo, Napoli 2003.

Cavallo, Calamo = Guglielmo Cavallo, Il calamo e il papiro. La scrittura greca dall'età ellenistica ai primi secoli di Bisanzio, Firenze 2005.

Cavallo, P.Mil. Vogl. I 19 = Guglielmo Cavallo, P.Mil. Vogl. I 19, Galeno e la produzione di libri greci a Roma in età imperiale, "Segno e Testo" 11 (2013), 1-14.

Cavallo, Scrittura = Guglielmo Cavallo, La scrittura greca e latina dei papiri. Una introduzione, Roma/Pisa 2008.

Cavallo/Fioretti, Chiaroscuro $=$ Guglielmo Cavallo $/$ Paolo Fioretti, Chiaroscuro. Oltre l'angolo di scrittura (secoli I A.C. - VI D.C.), "Scripta" 7 (2014), 29-64.

Cavenaile, Corpus = Robert Cavenaile, Corpus papyrorum Latinarum, Wiesbaden 1958.

Coles, Oxyrhynchus = Revel A. Coles, Oxyrhynchus: A City and its Texts, in: Bowman/Coles/ Gonis/Obbink, Oxyrhynchus, 3-16.

Coles, Reports $=$ Revel A. Coles, Reports of Proceedings in the Papyri, Bruxelles 1966.

Corcoran, Justinian = Simon Corcoran, Justinian and His Two Codes. Revisiting P.Oxy. 1814, JJP 38 (2008), 73-111.

Corcoran, Tales $=$ Simon Corcoran, Two Tales, Two Cities: Antinoopolis and Nottingham, in: J. Drinkwater / B. Salway (eds.), Wolf Liebeschuetz Reflected. Essays Presented by Colleagues, Friends, \& Pupils, London 2007, 193-209.

CPSGL B, 1.1 = Roberto Funari (ed.), Corpus dei papiri storici greci e latini, B (Storici latini), 1 (autori noti), 1, Titus Livius, Pisa/Roma 2011.

CPSGL B, 1.2 = Roberto Funari (ed.), Corpus dei papiri storici greci e latini, B (Storici latini), 1 (autori noti), 2, Caius Sallustius Crispus, Pisa/Roma, 2008.

Cribiore, Writing = Raffaella Cribiore, Writing, Teachers, and Students in Graeco-Roman Egypt, Atlanta 1996.

Cribiore, Literacy = Raffaella Cribiore, Latin Literacy in Egypt, "Kodai" 13-14 (2003-04), 111-8.

Crisci, Scrivere = Edoardo Crisci, Scrivere greco fuori d'Egitto. Ricerche sui manoscritti grecoorientali di origine non egiziana dal IV secolo a.C. all'VIII d.C., Firenze 1996.

Dagron, Origines = Gilbert Dragon, Aux origines de la civilization byzantine: langue de culture et langue d'état, "Revue historique" 241 (1969), 23-56. 
Daris, Documenti = Sergio Daris, Documenti per la storia dell'esercito romano in Egitto, Milano 1965.

Davoli, Archeologia = Paola Davoli, Archeologia e papiri, Napoli 2001.

Del Corso, Cultura = Lucio Del Corso, Cultura scritta e scritture esposte: le iscrizioni di Leptis Magna dall'età dei Severi al tardoantico, in: I. Tantillo / F. Bigi (eds.), Leptis Magna. Una città e le sue iscrizioni in epoca tardoromana, Cassino 2010, 205-18.

Del Corso, Dioscoro = Lucio Del Corso, Le scritture di Dioscoro, in: Fournet, Dioscore, 89-115.

Del Corso, Osservazioni = Lucio Del Corso, Osservazioni sulla datazione di alcuni frammenti di codici da Antinoupolis, in: M. Capasso / M. De Nonno (eds.), Studi paleografici e papirologici in ricordo di Paolo Radiciotti, Lecce 2015, 169-92.

Del Francia Barocas, Antinoe = Loretta Del Francia Barocas (ed.), Antinoe cent'anni dopo. Catalogo della mostra. Firenze Palazzo Medici Riccardi 10 luglio - $1^{\circ}$ novembre 1998, Firenze 1998.

Dickey, Speakers = Eleanor Dickey, How Coptic Speakers Learned Latin? A Reconsideration of P.Berol. inv. 10582, ZPE 193 (2015), 65-77.

Fink, Records = Robert O. Fink, Roman Military Records on Papyrus, Princeton 1971.

Fournet, Antinoupolis = Jean-Luc Fournet, I papiri di Antinoupolis. La collezione e gli scavi fiorentini, in: G. Bastianini / A. Casanova (eds.), 100 anni di istituzioni fiorentine per la papirologia. 1908. Società Italiana per la ricerca dei Papiri. 1928. Istituto Papirologico "G. Vitelli”, Atti del convegno internazionale di studi, Firenze, 12-13 giugno 2008, Firenze 2009, 115-32.

Fournet, Dioscore = Jean-Luc Fournet (ed.), Les archives de Dioscore d'Aphrodité cent ans après leur découverte. Histoire et culture dans l'Égypte byzantine, Paris 2008.

Fournet, Document = Jean-Luc Fournet, Entre document et littérature. La pétition dans l'antiquité tardive, in: D. Feissel / J. Gascou (eds.), La pétition à Byzance, Paris 2004, 61-74.

Fournet, Environment = Jean-Luc Fournet, The Multilingual Environment of Late Antique Egypt: Greek, Latin, Coptic, and Persian Documentation, in: Bagnall, Handbook, 418-51.

Fournet, Hellénisme = Jean-Luc Fournet, Hellénisme dans l'Égypte du VI siècle. La bibliotheque et l'oeuvre de Dioscore d'Aphodité, Le Caire 1999.

Fournet, Langues= Jean-Luc Fournet, Langues, écritures et culture dans les praesidia, in: H. Cuvigny (ed.), La route de Myos Hormos. L'armée romaine dans le désert Oriental d'Égypte, Le Caire 2003, 427-500.

Fressura, Tipologie = Marco Fressura, Tipologie del glossario virgiliano, in: Marganne/Rochette, Bilinguisme, 71-116.

Fressura, Vergilius = Marco Fressura, Vergilius Latinograecus. Corpus dei manoscritti bilingui dell'Eneide, parte prima (1-8), Pisa/Roma 2017.

Grafton/Williams, Christianity = Anthony Grafton / Megan Williams, Christianity and the Transformation of the Book. Origen, Eusebius, and the Library of Caesarea, Harvard 2006.

Haas, Alexandria $=$ Christian Haas, Alexandria in Late Antiquity. Topography and Social Conflict, Baltimore/London 1997.

Harrauer, Handbuch = Hermann Harrauer, Handbuch der griechischen Paläographie, Stuttgart 2010.

Harrauer/Pintaudi, Miscellanea $=$ Hermann Harrauer / Rosario Pintaudi, Miscellanea di tachigrafia, AnPap 14-15 (2002-03), 117-64.

Hunt/Johnson, Theocritus = Arthur S. Hunt / John Johnson, Two Theocritus Papyri, London 1930.

Internullo, Cicerone $=$ Dario Internullo, Cicerone latinogreco. Corpus dei papiri bilingui delle Catilinarie di Cicerone, PapLup 20-21 (2011-12), 27-150.

Johnson, Antinoë = John de Monins Johnson, Antinoë and Its Papyri: Excavations by the GraecoRoman Branch, 1913-14, "Journal of Egyptian Archaeology" 1 (1914), 168-81.

Johnson, Book = William Johnson, The Ancient Book, in: Bagnall, Handbook, 256-81.

Keenan, Egypt $=$ James Keenan, Egypt, in: Averil Cameron / Bryan Ward-Perkins / Michael Whitby (eds.), Cambridge Ancient History XIV. Late Antiquity: Empire and Successors, A.D. 425-600, Cambridge 2000, 612-37. 
Kramer, Alltagsdokuments = Johannes Kramer, Vulgärlateinische Alltagsdokuments auf Papyri, Ostraka, Täfelchen und Inschriften, Berlin/New York 2007.

Lowe, Symptoms = Elias A. Lowe, Greek Symptoms in a Sixth-Century Manuscript of St. Augustine and in a Group of Latin Legal Manuscripts, in: S. Prete (ed.), Didascaliae. Studies in Honor of Anselm M. Albareda, New York 1961, 277-89 [repr. in Id., Palaeographical Papers. 1907-1965, Oxford 1972, II, 466-74].

MacCoull, Dioscorus = Leslie S. B. MacCoull, Dioscorus of Aphrodito. His Work and His World, Berkeley/Los Angeles/London 1989.

Malouta, Archive = Myrto Malouta, Roman Empire and British Imperialism: the Private Archive of J. De M. Johnson's Excavation in Antinoopolis, AnPap 27 (2015), 203-30.

Marganne, Crossroads = Marie-Hélène Marganne, At the Crossroads of Greek and Roman Medicine: The Contribution of Latin Papyri, 1. Medical Texts, in: Brigitte Maire (ed.), 'Greek' and 'Roman' in Latin Medical Texts. Studies in Cultural Change and Exchange in Ancient Medicine, Leiden/Boston 2014, 92-103.

Marganne/Rochette, Bilinguisme = Marie-Hélène Marganne / Bruno Rochette (eds.), Bilinguisme et digraphisme dans le monde gréco-romain, Liège 2013.

McNamee, Annotations = Kathleen McNamee, Annotations in Greek and Latin Texts from Egypt, Chippenham 2007.

Menchetti/Pintaudi, Ostraka = Angiolo Menchetti / Rosario Pintaudi, Ostraka greci e bilingui da Narmuthis, CE 82 (2007), 227-80.

Menci, Papiri = Giovanna Menci, I papiri letterari 'sacri' e 'profani' di Antinoe, in: Del Francia Barocas, Antinoe, 49-55.

Migliardi Zingale, Diritto = Livia Migliardi Zingale, Sui libri di diritto romano conservati nelle fonti papirologiche: alcune riflessioni, "Minima epigraphica et papyrologica" 7-8 (2004-05), 347-56.

Migliardi Zingale, Dottrina $=$ Livia Migliardi Zingale, Libri di dottrina romana e fonti papirologiche: riflessioni in margine ad alcune recenti acquisizioni, in: Testi giuridici $e$ letterari per la storia del diritto tardoantico. Atti del XV Convegno Internazionale dell'Accademia Romanistica Costantiniana, Napoli 2005, 221-37.

Milne, Shorthand = Herbert J. M. Milne, Greek Shorthand Manuals. Syllabary and Commentary, London 1934.

Minutoli, Considerazioni $=$ Diletta Minutoli, Considerazioni su PSI XIII 1299 e 1306, AnPap 26 (2014), 83-98.

Mitthof, Annona = Fritz Mitthof, Annona militaris. Die Heeresversorgung im spätantiken Ägypten. Ein Beitrag zur Verwaltungs- und Heeresgeschichte des Römischen Reiches im 3. bis 6. Jh. n. Chr., Firenze 2001.

Nicolaj, Ambiti = Giovanna Nicolaj, Ambiti di copia e copisti di codici giuridici in Italia, in: I. Birocchi / M. Caravale / E. Conte / U. Petronio (eds.), A Ennio Cortese, Roma 2001, II, pp. 478-96 [repr. in Ead., Storie di documenti. Storie di libri, Dietikon/Zürich 2013, 349-62].

Nocchi Macedo, Juvenal $=$ Gabriel Nocchi Macedo, Juvenal in Antinoë. Paleographic and Contextual Observations on P.Ant. s.n., in: T. Derda / A. Łajtar / J. Urbanik (eds.), Proceedings of the $27^{\text {th }}$ International Congress of Papyrology (Warsaw, 29 July-3 August 2013), Warsaw 2016, 167-83.

O'Connell, Johnson = Elizabeth O'Connell, John de Monins Johnson 1913/14 Egypt Exploration Fund Expedition to Antinoupolis (Antinoë), with Appendix of Objects, in: R. Pintaudi (ed.), Antinoupolis II, Firenze 2014, 415-66.

Palme, Texts = Bernhard Palme, The Range of Documentary Texts: Types and Categories, in: Bagnall, Handbook, 358-94.

Pellé, Livre = Natascia Pellé, Le livre d'histoire dans les papyrus, Liége 2011.

Pfeiffer, Scholarship = Rudolf Pfeiffer, History of Classical Scholarship. From the Beginning to the End of the Hellenistic Age, Oxford 1968. 
Pratesi, Divagazioni = Alessandro Pratesi, Nuove divagazioni per uno studio della scrittura capitale. I "codices Vergiliani antiquiores", "Scrittura e Civiltà" 9 (1985), 5-33.

Pratesi, Frustula = Alessandro Pratesi, Frustula Palaeographica, Firenze 1992.

Radiciotti, Digrafismo = Paolo Radiciotti, Digrafismo nei papiri latini, in: Marganne/Rochette (eds.), Bilinguisme, 57-69.

Roberts, Juvenal = Colin H. Roberts, The Antinoë Fragment of Juvenal, "Journal of Egyptian Archaeology" 21 (1935), 199-209.

Rochette, Latin = Bruno Rochette, Le latin dans le monde grec. Recherches sur la diffusion de la langue et des lettres latines dans le provinces hellénophones de l'Empire romain, Bruxelles 1997.

Ruffini, Networks = Giovanni Ruffini, Late Antique Pagan Networks from Athens to the Thebaid, in: W. V. Harris / G. Ruffini (eds.), Ancient Alexandria between Egypt and Greece, Leiden/ Boston 2004, 241-57.

Scappaticcio, Abecedari = Maria Chiara Scappaticcio, Abecedari su papiro, alfabeti latini, "Bollettino di Studi Latini” 42 (2013), 476-97.

Scappaticcio, Artes = Maria Chiara Scappaticcio, Artes Grammaticae in frammenti. I testi grammaticali latini e bilingui greco-latini su papiro: edizione commentata, Berlin/Boston 2015.

Scappaticcio, Papyri = Maria Chiara Scappaticcio, Papyri Vergilianae. L'apporto della papirologia alla storia della tradizione virgiliana (I-VI d.C.), Liège 2013.

Seider Paläographie = Richard Seider, Paläographie der lateinischen Papyri, I-II.2, Stuttgart 1972-81.

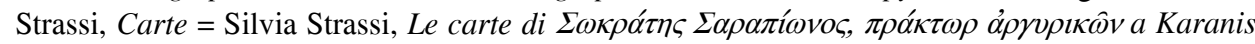
nel II sec. d.C., in: I. Andorlini / G. Bastianini / M. Manfredi / G. Menci (eds.), Atti del XXII Congresso Internazionale di Papirologia, Firenze, 23-29 agosto 1998, Firenze 2001, 1215-28.

Strassi, Tiberianus $=$ Silvia Strassi, L'archivio di Claudius Tiberianus da Karanis, Berlin/New York 2008.

Thomas, Texts = James D. Thomas, Latin Texts and Roman Citizens, in: Bowman/Coles/Gonis/ Obbink, Oxyrhynchus, 231-43.

Turner, Branch = Eric G. Turner, The Graeco-Roman Branch of the Egypt Exploration Society, in: Bowman/Coles/Gonis/Obbink, Oxyrhynchus, 17-27.

Turner, Papyri = Eric G. Turner, Greek Papyri. An Introduction, Oxford 1968.

Van Minnen, Karanis = Peter van Minnen, House-to-House Enquiries: An Interdisciplinary Approach to Roman Karanis, ZPE 100 (1994), 227-51. 